\title{
PENGARUH IMPLEMENTASI STANDAR AKUNTANSI PEMERINTAHAN BERBASIS AKRUAL DAN EFEKTIVITAS FUNGSI PENGAWASAN TERHADAP KINERJA KEUANGAN PEMERINTAH DAERAH KABUPATEN ACEH BESAR
}

\author{
Iin Novianti ${ }^{1}$, Syamsidar ${ }^{2}$, Cut Fitrika Syawalina ${ }^{3}$ \\ muhammad.arafah95@gmail.com \\ Fakultas Ekonomi Universitas Muhammadiyah Aceh
}

\begin{abstract}
The purpose of this study was to determine the effect of the implementation of accrual based government accounting standards and the effectiveness of supervisory functions on government financial performance in Great Aceh district.The sample in this study were 81 people from the total population. In data collection the researchers used questionnaires, and analysed the data qualitatively and quantitatively. The data analysi to find out the effect of the dependent and independent variables by using a multiple regression equation analysis. Test the hypothesis by using t-test, with the help of computer V.22.0 SPSS program for windows.

The results showed a positive linear relationship and quite tightly between the implementation of accounting governance standards based on accruals and the effectiveness of supervision functions on accountability of lo oversight of the financial performance of local government in Aceh Besar district. Further to the positive and significant influence of each independent variable on the financial performance of government in Great Aceh district.

It is necessary to accelerate the implementation of activities that have been budgeted previously, moreover the training that has been held should put forward the practice of the field to meet the human resource needs, while in the aspect of science and technology needed to accelerate the development of financial applications in order to produce the financial reports on an accrual basis.
\end{abstract}

Keywords : the implementation of accrual based government accounting standards, the effectiveness of supervisory functions, the financial performance of local government

\begin{abstract}
ABSTRAK
Tujuan penelitian ini adalah untuk mengetahui pengaruh implementasi standar akuntansi pemerintahan berbasis akrual dan efektivitas fungsi pengawasan terhadap kinerja keuangan pemerintah daerah kabupaten Aceh Besar. Sampel dalam penelitian ini sebanyak 81 orang dari seluruh total populasi. Pengumpulan data menggunakan kuesioner,dan analisa secara kualitatif dan kuantitatif. Analisis data untuk melihat pengaruh variabel terikat dengan variabel bebas menggunakan analisis persamaan regresi berganda. Uji hipotesis menggunakan uji statistik ttest,dengan bantuan program komputer program SPSS V.22.0 For windows.

Hasil penelitian memperlihatkan hubungan linier positif dan berhubungan cukup erat antara implementasi standar akuntansi pemerintahan berbasis akrual dan efektivitas fungsi pengawasan terhadap kinerja keuangan pemerintah daerah kabupaten Aceh Besar. Selanjutnya terdapat pengaruh positif dan signifikan dari masing-masing variabel bebas terhadap kinerja keuangan pemerintah daerah kabupaten Aceh Besar.
\end{abstract}


Perlu adanya percepatan pelaksanaan kegiatan-kegiatan yang telah dianggarkan sebelumnya, selain itu diklat yang diadakan harus lebih mengedepankan praktek di lapangan untuk memenuhi kebutuhan SDM, sedangkan dalam aspek IT diperlukan percepatan pengembangan aplikasi keuangan agar dapat menghasilkan laporan keuangan secara akrual.

\section{Kata kunci}

: Implementasi standar akuntansi pemerintahan berbasis akrual, efektivitas fungsi pengawasan, kinerja keuangan pemerintah daerah

\section{PENDAHULUAN / INTRODUCTION}

Kinerja pemerintah menunjukkan deskripsi dari tingkat pencapaian suatu kegiatan, program atau kebijakan organisasi dalam mencapai tujuan organisasi. Kinerja pemerintah saat ini menjadi sorotan publik karena kinerja menggambarkan hasil kerja yang dicapai pemerintah dalam melaksanakan tugas- tugas yang dibebankan kepadanya atas dasar kecakapan, pengalaman, serta keterampilan

Instansi pemerintah di Kabupaten Aceh Besar dibentuk untuk menangani urusanurusan pemerintahan dalam berbagai bidang, menjalankankan pelayanan publik serta menjadi fasilitator dalam pembangunan daerah. Reformasi pengelolaan dan pertanggungjawaban keuangan daerah yang telah berlangsung sejak tahun 2001 membuat kinerja instansi pemerintah di Kabupaten Aceh Besar semakin berperan dalam menentukan masa depan daerah.

Berdasarkan hasil survey awal diketahui bahwa pengelolaan keuangan daerah di Kabupaten Aceh Besar terus mengalami kenaikan setiap tahunnya sejalan dengan meningkatnya penerimaan daerah yang digunakan dalam pelaksanaan program kerja pemerintah, namun target dan realisasi program kerja pemerintah malah mengalami penurunan pada setiap tahunnya, bahkan pada tahun 2016 realisasi anggaran yang dicapai hanya $78,13 \%$ yang menurut pengukuran berdasarkan Value
For Money (Mardiasmo, 2012:5) berada pada kategori cukup efisien.

Basis akrual yang diterapkan Instansi pemerintah di Kabupaten Aceh Besar saat ini ternyata dapat menunjukkan bagaimana instansi ini dapat membiayai kegiatannya dan memenuhi kebutuhan kasnya. Akuntansi berbasis akrual menunjukkan posisi keuangan/kekayaan pemerintah dan perubahan atas posisi keuangan tersebut. Basis akrual memungkinkan pembaca laporan keuangan mengevaluasi kemampuan Instansi pemerintah di Kabupaten Aceh Besar saat ini untuk membiayai aktivitas-aktivitasnya dan untuk memenuhi kewajiban dan komitmenkomitmennya.

Akuntansi kas yang telah dilaksanakan Instansi pemerintah di Kabupaten Aceh Besar sebelum keluarnya Peraturan Pemerintah No 71 Tahun 2010 tidak dapat menyediakan informasi yang berkaitan dengan seluruh biaya (full costs) dari program kerja yang telah dilakukan oleh instansi karena sistem akuntansi barbasis kas yang diterapkan hanya mengakui arus kas masuk dan kas keluar. Pendapatan diakui pada saat diterima pada Rekening Kas Umum Negara/Daerah atau entitas pelaporan dan belanja diakui pada saat terjadinya pengeluaran dari Rekening Kas Umum Negara/Daerah.

Hasil wawancara singkat pada survey awal yang peneliti lakukan di Dinas Pengelolaan Keuangan dan Kekayaan Daerah (DPKKD) Kabupaten Aceh Besar, diketahui 
bahwa perubahan akuntansi kas ke akuntansi berbasis akrual butuh proses yang lama, karena kurangnya sumber daya manusia yang memiliki kemampuan dalam melakukan penyesuaian dengan cepat, sehingga masih banyak sumber daya manusia yang harus diberikan pelatihan atau sekolah singkat. Padahal Implementasi ini telah dilaksanakan sejak tahun 2010, namun hingga sekarang masih ada satu item laporan yang belum sempurna dilakukan, yaitu laporan perubahan saldo anggaran lebih.

Sebagaimana diketahui, pelaksanaan ketentuan Peraturan Pemerintah Nomor 71 tahun 2010 tentang Standar Akuntansi Pemerintahan, Pemkab Aceh Besar sudah melakukan penyusunan laporan keuangan dengan menerapkan akuntansi berbasis akrual. Selain Laporan Realisasi Anggaran (LRA), Laporan Arus Kas, Neraca dan Catatan Atas Laporan Keuangan, maka terdapat tiga laporan tambahan akibat dari pelaksanaan akuntansi berbasis akrual, yaitu laporan perubahan saldo anggaran lebih, laporan operasional, dan laporan perubahan ekuitas yang sudah diaudit oleh BPK RI.

Akibat dari belum sempurnanya laporan saldo anggaran lebih, maka sering terjadi kasus-kasus yang menyimpang seperti kelebihan pembayaran anggaran dari rencana anggaran semula. Kasus-kasus seperti itu dapat merugikan pemerintah dalam hal ini erat hubungannya dengan fungsi pengawasan..

Fungsi pengawasan menjadi masalah penting bagi pemerintah untuk menjamin terlaksananya program kerja pemerintah secara akuntabel. Meningkatnya kegiatan pengelolaan keuangan daerah dengan nilai anggaran yang lebih besar dan terperinci ke berbagai program kerja membuat fungsi pengawasan menjadi semakin penting untuk mencegah kecurangan dan penyimpangan serta mengarahkan penggunaan anggaran yang lebih optimal pada program kerja yang bermutu. Melalui pengawasan dapat diketahui apakah suatu instansi pemerintah telah melaksanakan kegiatan sesuai dengan tugas dan fungsinya serta telah menggunakan anggaran publik secara efektif dan efisien, serta sesuai dengan ketentuan yang telah ditetapkan.

Berdasarkan uraian sebelumnya, maka penulis tertarik untuk melakukan penelitian secara komprehensif dalam bentuk penelitian dengan judul:

Pengaruh Implementasi Standar Akuntansi Pemerintahan Berbasis Akrual Dan Efektivitas Fungsi Pengawasan Terhadap Kinerja Keuangan Pemerintah Daerah Kabupaten Aceh Besar.

\section{TINJAUAN KEPUSTAKAAN Kinerja Pemerintah}

Kinerja adalah sebagai hasil-hasil fungsi perkerjaan atau kegiatan dalam organisasi yang dipengaruhi oleh berbagai faktor untuk mencapai tujuan organisasi. Mulyadi (2011: 337) menyatakan kinerja adalah keberhasilan personel, tim, atau unit organisasi dalam mewujudkan sasaran strategik yang telah ditetapkan sebelumnya dengan perilaku yang diharapkan.

Menurut Bastian (2010: 274) menjelaskan kinerja organisasi adalah gambaran mengenai tingkat pencapaian pelaksanaan suatu kegiatan/program/kebijaksanaan dalam mewujudkan sasaran, tujuan, misi dan visi organisasi yang tertuang dalam perumusan skema strategis (strategic planning) suatu organisasi.

Menurut Nawawi (2013:48) menjelaskan kinerja pemerintah yang baik tidak hanya sekedar input atau output namun sebuah orientasi pada hasil. Kinerja pemerintah harus memiliki hasil, manfaat dan dampak yang positif bagi masyarakat, sehingga pencapaian serapan anggaran saja tidak dapat dijadikan ukuran yang memadai dan dapat meng- 
gambarkan manajemen kinerja pemerintahan yang baik.

Sebuah instansi pemerintah dapat dikatakan berhasil melaksanakan tugasnya jika indikator atau ukuran capaian sasaran kinerja sesuai atau searah dengan misi yang telah dirumuskan. Indikator kinerja tersebut didasarkan pada kelompok menurut masukan (input), keluaran (output), hasil (outcome), manfaat (benefit), dampak (impact) serta proses (process) (Adisasmita, 2011:90). Menurut Mardiasmo (2010: 122) dalam Putri (2012) manfaat pengukuran kinerja adalah sebagai berikut :

1. Memberikan pemahaman mengenai pengukuran yang digunakan untuk menilai kinerja manajemen;

2. Memberikan arah untuk mencapai target kinerja yang telah ditetapkan;

3. Untuk memonitor dan mengevaluasi pencapaian kinerja dan membandingkannya dengan target kinerja serta melakukan tindakan korektif untuk memperbaiki kinerja;

4. Sebagai dasar untuk memberikan pengharapan dan hukuman (reward \& punishment) secara obyektif atas pencapaian prestasi yang diukur sesuai dengan sistem pengukuran kinerja yang telah diperbaiki;

5. Sebagai alat komunikasi antara bawahan dan pimpinan dalam rangka memperbaiki kinerja organisasi;

6. Membantu mengidentifikasi apakah kepuasan pegawai sudah terpenuhi; Membantu memahami proses kegiatan intansi pemerintah;

7. Memastikan bahwa pengambilan keputusan dilakukan secara obyektif.

Kinerja menurut Mahmudi (2013:20) merupakan suatu kosntrukmultidimensi yang dipengaruhi oleh banyak faktor antara lain.

1. Faktor personal individu meliputi pengetahuan, keterampilan, kemampuan, kepercayaan, motivasi dan komitmen yang dimiliki individu.

2. Faktor kepemimpinan meliputi kualitas dalam memberi dorongan, semangat, arahan dan dukungan yang diberikan manajer.

3. Faktor tim, kualitas dalam member dukungan, semangat yang diberikan oleh rekan tim, kepercayaan terhadap sesame anggota tim, kekompakan dan keeratan anggota tim.

4. Faktor sistem meliputi system kerja, fasiliats kerja atau infrastruktur, yang diberikan oleh organisasi proses organisasi dan kultur kinerja dalam organisasi

5. Faktor eksternal meliputi tekanan dan perubahan lingkungan eksternal dan internal.

\section{Kinerja Keuangan Sektor Publik}

Menurut Inpres No. 7 Tahun 1999 tentang akuntabilitas kinerja instansi pemerintah, kinerja adalah gambaran mengenai tingkat pencapaian pelaksanaan suatu kegiatan/program/kebijaksanaan dalam mewujudkan sasaran, tujuan, misi, dan visi dari organisasi pemerintahan.

Suprapto (2011:84) menyebutkan salah satu alat untuk menganalisis kinerja pemerintah daerah dalam mengelola keuangan daerahnya adalah dengan melaksanakan analisis rasio terhadap APBD yang telah ditetapkan dan dilaksanakannya. Penggunaan analisis rasio pada sektor publik belum banyak dilakukan, sehingga secara teori belum ada kesepakatan secara bulat mengenai nama dan kaidah pengukurannya. Meskipun demikian, dalam rangka pengelolaan keuangan daerah yang transparan, jujur, demokratis, efektif, efisien dan akuntabel, analisis rasio terhadap APBD perlu dilaksanakan meskipun pengakuntasian dalam APBD berbeda dengan laporan keuangan yang dimiliki perusahaan swasta. Analisis rasio keuangan pada APBD dilakukan dengan membandingkan hasil yang 
dicapai dari satu periode dibandingkan dengan periode sebelumnya sehinggga dapat diketahui bagaimana kecenderungan yang terjadi. Selain itu dapat pula dilakukan dengan cara membandingkan dengan rasio keuangan pemerintah daerah tertentu dengan rasio keuangan daerah lain yang terdekat ataupun potensi daerahnya relatif sama untuk dilihat bagaimana posisi keuangan pemerintah daerah tersebut terhadap pemerintah daerah lainnya.

Analisis rasio keuangan pada APBD dilakukan dengan membandingkan hasil yang dicapai dari satu periode dibandingkan dengan periode sebelumnya sehingga dapat diketahui kecenderungan yang terjadi (Halim, 2014). Salah satu rasio yang digunakan untuk mengukur kinerja keuangan pemerintah daerah menurut Mardiasmo (2012:4) adalah menggunakan pengukuran value for money, dengan melihat rasio efektivitas dari kinerja keuangan pemerintah daerah tersebut.

Rasio efektifitas menggambarkan kemampuan pemerintah daerah dalam merealisasikan Pendapatan Asli Daerah yang direncanakan dibandingkan dengan target yang ditetapkan berdasarkan potensi riil daerah. Hubungan antara input dan output dimana barang dan jasa yang dibeli oleh organisasi digunakan untuk mencapai output tertentu. Efektivitas dapat diukur dengan membandingkan rasio antara output dan input. Semakin besar rasio berarti semakin tinggi tingkat efektivitasnya.

$$
\text { Rasio Efektivitas }=\frac{\text { Output }}{\text { Input }} \times \mathbf{1 0 0 \%}
$$

Dimana nilai output merupakan hasil persentase perhitungan realisasi fisik lapangan dari setiap kegiatan yang ada, sedangkan nilai input merupakan persentase antara dana yang digunakan dengan dana yang dianggarkan oleh pemerintah. Selanjutnya untuk pengukuran nilai efektivitas dari setiap realisasi kegiatan yang dianggarkan, maka digunakan interval skala persentase. Adapun skala persentase tersebut adalah:

- $90 \mathrm{~s} / \mathrm{d} 100=$ Sangat efektif

- $80 \mathrm{~s} / \mathrm{d} 89,99=$ Efektif

- $70 \mathrm{~s} / \mathrm{d} 79,99=$ Cukup efektif

- $60 \mathrm{~s} / \mathrm{d} 69,99=$ Kurang efektif

- $<59,99=$ Tidak efektif

Dari pengertian di atas dapat ditarik kesimpulan bahwa kinerja keuangan publik adalah usaha formal yang dilakukan dalam rangka pemberdayaan yang bertujuan dan bertumpu pada kepentingan publik.

\section{Sistem Akuntansi Berbasis Akrual}

Menurut Rasdianto (2013:10) sistem akuntansi berbasis akrual adalah akuntansi yang mengakui dan mencatat transaksi atau kejadian keuangan pada saat terjadi atau pada saat perolehan. Fokus sistem akuntansi ini pada pengukuran sumber daya ekonomis dan perubahan sumber daya pada suatu entitas. Dalam akuntansi akrual informasi yang dihasilkan jauh lebih lengkap dan menyediakan informasi yang lebih rinci mengenai aktiva dan kewajiban.

Menurut Nunuy (2010:17) Akuntansi berbasis akrual merupakan sistem akuntansi yang mengakui dan mencatat transaksi atau kejadian keuangan pada saat terjadi atau pada saat perolehan. Fokus sistem akuntansi ini pada pengukuran sumber daya ekonomis dan perubahan sumber daya pada suatu entitas.

Halim dan Kusufi (2012: 53) dalam Lamonisi (2016) menyimpulkan bahwa basis akrual mampu memenuhi tujuan pelaporan yang tidak dapat dipenuhi oleh basis kas, tujuan pelaporan tersebut adalah tujuan manajerial dan pengawasan. Beberapa masalah aplikasi basis akrual yang dapat diidentifikasikan antara lain (Bastian, 2010: 120) dalam Lamonisi (2016) adalah:

1. Penentuan pos dan besaran transaksi yang dicatat dalam jurnal dilakukan oleh individu yang mencatat. 
2. Relevansi akuntansi akrual menjadi terbatas ketika dikaitkan dengan nilai historis dan inflasi.

3. Dalam pembandingan dengan basis kas, penyesuaian akrual membutuhkan prosedur administrasi yang lebih rumit, sehingga biaya admnistrasi menjadi lebih mahal.

4. Peluang manipulasi keuangan yang sulit dikendalikan.

Menurut Kementerian Keuangan Republik Indonesia (2014) basis akuntansi akrual memiliki manfaat sebagai berikut:

1. Memberikan gambaran yang utuh atas posisi keuangan pemerintah

2. Menyajikan informasi yang sebenarnya mengenai hak dan kewajiban pemerintah

3. Bermanfaat dalam mengevaluasi kinerja pemerintah terkait biaya jasa layanan, efisiensi, dan pencapaian tujuan.

\section{Indikator Sistem Akuntansi Berbasis}

\section{Akrual}

Nordiawan (2012:201) menjelaskan lebih rinci unsur dari sistem akuntansi keuangan secara umum terdiri dari (1) pencatatan, (2) pengikhtisaran dan (3) pelaporan. Adapun penjelasan sistem akuntansi keuangan sebagai berikut:

1) Pencatatan

a) Kegiatan pengidentifikasian dan pengukuran dalam bentuk bukti transaksi dan bukti pencatatan.

b) Kegiatan pencatatan bukti transaksi dalam buku harian atau jurnal.

c) Memindahbukukan (posting) dari jurnal berdasarkan kelompok atau jenisnya ke dalam akun buku besar.

2) Pengikhtisaran

a) Penyusunan neraca saldo berdasarkan akun buku besar pada akhir periode akuntansi yaitu suatu daftar yang memuat nama akun atau rekening beserta jumlah saldonya selama periode tertentu, diambil dari buku besar. b) Pembuatan ayat jurnal penyesuaian yaitu menyesuaikan akun-akun pada akhir periode yang belum menyajikan informasi yang paling up to date.

c) Penyusunan kertas kerja atau neraca lajur yaitu neraca lajur merupakan alat pembantu penyusunan laporan keuangan.

d) Pembuatan ayat jurnal penutup yaitu prosedur jurnal penutup diposting ke akun-akun bersangkutan sehingga setelah diposting, akun nominal akan nol.

e) Pembuatan neraca saldo setelah penutupan yaitu neraca yang berisi daftar akun riil yang dibuat yang dibuat setelah dilakukan penutupan.

f) Pembuatan jurnal pembalik diperlukan apabila setelah pembuatan neraca saldo setelah penutupan, dibuat ayat jurnal pembalik.

3) Pelaporan

Setelah proses selesai, maka dalam rangka pertanggungjawaban pelaksanaan APBD, entitas pelaporan menyusun laporan keuangan.

Kerangka konseptual dari pengukuran (nilai perolehan historis) unsur laporan keuangan, yaitu :

1. Pengukuran Aset

Dicatat sebesar pengeluaran/penggunaan sumber daya ekonomi atau sebesar nilai wajar dari imbalan yang diberikan untuk memperoleh aset tersebut.

2. Pengukuran Kewajiban

Dicatat sebesar nilai wajar sumber daya ekonomi yang digunakan pemerintah untuk memenuhi kewajiban yang bersangkutan".

Dalam penerapan basis akrual nantinya, pemerintah diwajibkan untuk menyusun tujuh laporan keuangan, yakni Laporan Realisasi Anggaran (LRA), Laporan Perubahan Saldo Anggaran Lebih, Neraca, Laporan Arus Kas (LAK), Laporan Operasional (LO), Laporan 
Perubahan Ekuitas (LPE), dan Catatan atas Laporan Keuangan (CaLK). Perbedaan mendasar antara basis CTA dengan basis akrual terletak pada LRA dan LO.

\section{Fungsi Pengawasan}

Secara umum yang dimaksud pengawasan menurut Sumarsono (2010:245) adalah segala kegiatan dan tindakan untuk menjamin agar penyelenggaraan suatu kegiatan tidak menyimpang dari tujuan serta rencana yang telah digariskan. Menurut Soeradi (2014:35) pengawasan adalah suatu kegiatan untuk memperoleh kepastian apakah pelaksanaan kegiatan telah dilakukan sesuai dengan rencana, aturan-aturan dan tujuan yang telah ditetapkan.

Pengawasan keuangan daerah sesungguhnya merupakan bagian integral dari pengelolaan keuangan negara secara keseluruhan. Bila dikaitkan dengan siklus anggaran, maka pengawasan keuangan negara meliputi tahap penyusunannya, tahap pelaksanaannya, maupun tahap pertanggungjawabannya. SAS (Statement on Auditing Standard) dalam Primadona (2011) mendefinisikan pengawasan adalah sebagai berikut:

1. Pengawasan administrasi, meliputi struktur organisasi, prosedur dan catatan yang berhubungan dengan proses pengambilan keputusan untuk melaksanakan transakasi yang diotorisasi oleh manajemen.

2. Pengawasan akuntansi, meliputi struktur organisasi serta prosedur dan catatan yang berhubungan dengan usaha untuk menjaga keamanan aktiva dan dipercayainya catatan keuangan perusahaan.

\section{Penelitian Sebelumnya}

Penelitian Wina dan Khairani (2015) pengaruh penerapan standar pelaporan akuntansi sektor publik dan pengawasan terhadap akuntabilitas Kinerja instansi pemerintah (studi kasus Dispenda Kota dan
Dishub Prov). Hasil penelitian mengemukakan bahwa secara parsial maupun simultan penerapan standar pelaporan akuntansi sektor publik dan pengawasan berpengaruh signifikan terhadap akuntabiliats kinerja instansi pemerintah daerah.

Penelitian Dharma (2014) tentang pengaruh pengawasan fungsional dan penerapan sistem akuntansi terhadap akuntabilitas Instansi Pemerintah Daerah Kota Pariaman. Hasil penelitian menunjukkan pengawasan fungsional berpengaruh signifikan terhadap akuntabilitas instansi pemerintah, dan penerapan sistem akuntansi tidak berpengaruh signifikan terhadap akuntabilitas instansi pemerintah.

Penelitian Wibawa et.al (2013) Pengaruh Implementasi Standar Akuntansi Pemerintahan Berbasis Akrual Dan Efektivitas Fungsi Pengawasan Terhadap Kinerja Keuangan Pada Pemerintah Daerah Kota Tegal. Hasil penelitian menunjukan bahwa hasil pengujian korelasi pearson terhadap variable implementasi standar akuntansi pemerintahan berbasis akrual dan Efektivitas Fungsi Pengawasan memiliki hubungan yang sangat kuat/erat dengan kualitas laporan keuangan. Hasil pengujian regresi secara simultan dengan uji $\mathrm{F}$ maupun parsial dengan uji t, memperlihatkan bahwa implementasi standar akuntansi pemerintahan dan Efektivitas Fungsi Pengawasan berpengaruh secara signifikan terhadap kualitas laporan keuangan.

Penelitian Sukmana dan Lia (2009) tentang pengaruh pengawasan intern dan pelaksanaan sistem akuntansi keuangan daerah terhadap kinerja pemerintah daerah pada Satuan Kerja Perangkat Daerah Kota Tasikmalaya. Hasil penelitian mengemukakan bahwa secara parsial maupun simultan pengawasan intern dan pelaksanaan sistem akuntansi keuangan daerah berpengaruh signifikan terhadap kinerja pemerintah daerah.

\section{Hipotesis}


Berdasarkan uraian tujuan penelitian sebelumnya, penelitian terdahulu dan kerangka pemikiran dan sebelumnya, maka dapat dirumuskan hipotesis penelitian adalah

$\mathrm{H}_{1}$ ： Implementasi standar akuntansi pemerintahan berbasis akrual berpengaruh terhadap kinerja keuangan Pemerintah Kabupaten Aceh Besar.

$\mathrm{H}_{2}$ : Efektivitas fungsi pengawasan berpengaruh terhadap kinerja keuangan Pemerintah Kabupaten Aceh Besar.

$\mathrm{H}_{3}$ : Implementasi standar akuntansi pemerintahan berbasis akrual dan efektivitas fungsi pengawasan berpengaruh terhadap kinerja keuangan Pemerintah Kabupaten Aceh Besar.

\section{METODE PENELITIAN / METHODS}

\section{Lokasi dan Objek Penelitian}

Penelitian ini dilaksanakan pada pemerintah Daerah Kabupaten Aceh Besar yang berlokasi di Kota Jantho. Objek penelitian adalah implementasi standar akuntansi pemerintahan berbasis akrual, efektivitas fungsi pengawasan dan kinerja Keuangan pemerintah. Selain itu juga disajikan karakteristik responden pemerintah daerah Kabupaten Aceh Besar.

\section{Populasi dan Sampel}

Populasi dalam penelitian ini adalah Pegawai yang terlibat dalam bagian akuntansi pada SKPD Kabupaten Aceh Besar sebanyak 27 Kantor. Setiap kantor diwakili 3 bagian sub keuangan,yang terdiri dari kepala sub keuangan, bendahara dan staff keuangan,sehingga jumlah sampel dalam penelitian ini berjumlah 81 orang dari seluruh bagian keuangan di SKPD Kabupaten Aceh Besar.

\section{Teknik Pengumpulan Data}

Untuk memperoleh data mengenai implementasi standar akuntansi pemerintahan berbasis akrual dan efektivitas fungsi pengawasan terhadap kinerja Keuangan pemerintah dilakukan pengumpulan data dengan menggunakan Kuesioner. Kuesioner adalah sejumlah pertanyaan tertulis yang digunakan untuk memperoleh informasi dari responden Pertanyaan yang digunakan dalam kuesioner adalah tertutup yaitu berbentuk pilihan yang telah disediakan. Kuesioner terdiri dari 3(tiga) pertanyaan tentang karakterisik responden, 6 (enam) pertanyaan tentang kinerja instansi pemerintah dan 4 (empat) pertanyaan tentang penerapan akuntansi akrual basis dan 5 (lima) pertanyaan tentang efektivitas fungsi pengawasan.

\section{Teknik Analisis Data}

Untuk mengetahui pengaruh implementasi standar akuntansi pemerintahan berbasis akrual, efektivitas fungsi pengawasan terhadap kinerja keuangan pemerintah Daerah Kabupaten Aceh Besar digunakan analisis regresi adalah sebagai berikut:

$\mathbf{Y}=\boldsymbol{\alpha}+\boldsymbol{\beta}_{1} \mathbf{X}_{1}+\boldsymbol{\beta}_{2} \mathbf{X}_{2}+\mathrm{e}$

Keterangan:

$\mathrm{Y}=$ Kinerja keuangan

$\mathrm{X}_{1}=$ Implementasi standar akuntansi pemerintahan berbasis akrual

$\mathrm{X}_{2}=$ Efektivitas fungsi pengawasan

$\beta=$ Koefisien Regresi

$\alpha=$ Konstanta

e $\quad=$ Standart error

\section{Pengujian Hipotesis}

\section{Secara Parsial}

Pengujian ini di lakukan untuk mengetahui tingkat signifikansi pengaruh masing-masing variabel independen secara parsial terhadap variabel dependent. Yang menjadi Kriteria dalam pengujian hipotesis ini adalah :

$\begin{aligned} \text { Ho : } & \beta_{1}=0 \text { Implementasi standar } \\ & \text { akuntansi pemerintahan berbasis } \\ & \text { akrual tidak berpengaruh terhadap } \\ & \text { kinerja keuangan Pemerintah } \\ & \text { Kabupaten Aceh Besar. } \\ \mathrm{H}_{1}: & \beta_{1} \neq 0 \text { Implementasi standar } \\ & \text { akuntansi pemerintahan berbasis }\end{aligned}$


akrual berpengaruh terhadap kinerja keuangan Pemerintah Kabupaten Aceh Besar.

Dan

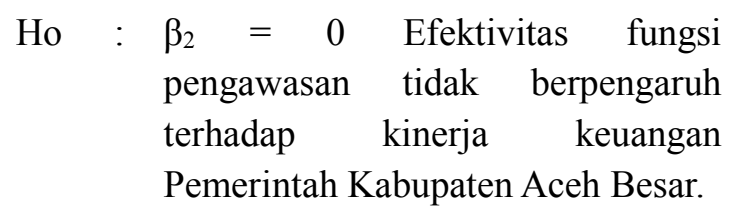

$\mathrm{H}_{1} \quad \beta_{2} \neq 0$ Efektivitas fungsi pengawasan berpengaruh terhadap kinerja keuangan Pemerintah Kabupaten Aceh Besar.

Uji parsial ini sering disebut dengan uji $t$ (uji 2 arah) yang mana dengan uji ini apakah hipotesis yang di gunakan di terima dan di tolak dengan ketentuan apabila hasil uji $\mathrm{t}$ dengan tingkat kepercayaan (confidence interval) $95 \%$ dengan $\alpha=0,05$ jika hasil thitung lebih besar dari t-tabel maka Ho diterima dan $\mathrm{H} 1$ ditolak.

\section{Secara simultan/serempak ( uji-F)}

Pengujian ini di lakukan untuk mengetahui signifikansi pengaruh seluruh variabel independen dalam model terhadap variabel dependent. Untuk menguji hipotesis yang di ajukan apakah di terima atau di tolak, variabel $\mathrm{X}$ berpengaruh terhadap $\mathrm{Y}$ maka di gunakan uji statistik uji F, adapun yang menjadi kriteria adalah:

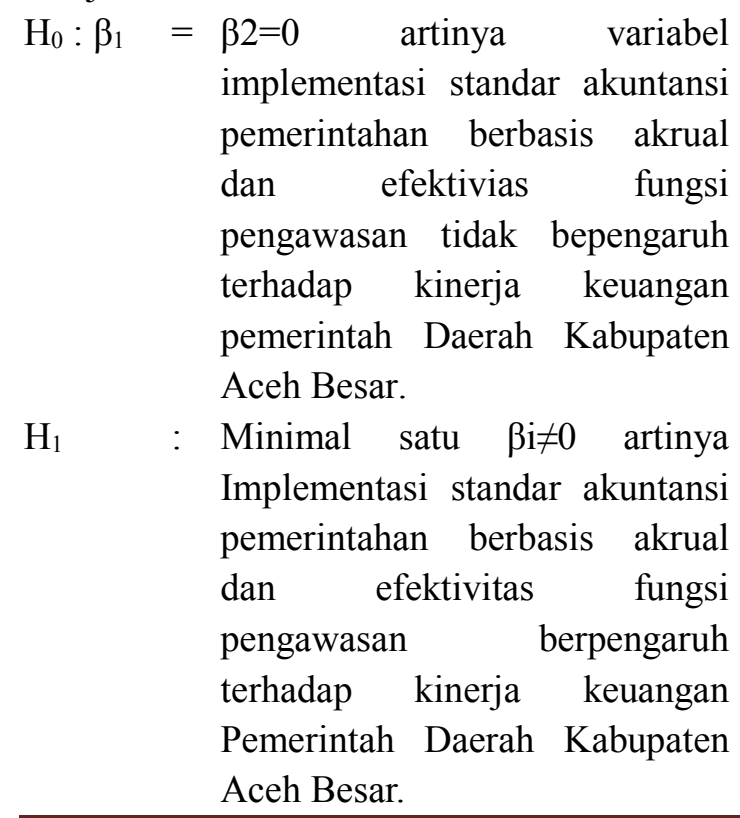

Pengujian ini di lakukan dengan uji statistik $\mathrm{F}$ dengan kriteria: Jika $\mathrm{F}_{\text {hitung }} \geq \mathrm{F}$ tabel, maka menerima Ha dan menolak Ho,Jika $\mathrm{F}_{\text {hitung }}<\mathrm{F}_{\text {tabel, }}$ maka menolak Ha dan menerima Ho. Dengan menggunakan spss versi 22 akan di lihat pada tabel ANOVA ataupun dengan membandingkan sig. F dengan level of test $(\alpha)$ dengan ketentuan Terima Ho bila sig. $\mathrm{F} \geq \alpha$ dan Tolak Ho( Terima H1) bila sig. $\mathrm{F} \leq \alpha$.

\section{HASIL PENELITIAN / RESULTS Karakteristik Responden}

Karakteristik responden menggambarkan identitas responden yang dilihat dari segi umur, jenis kelamin, pendidikan terakhir, dan pengalaman kerja, yang diperoleh dari hasil pengedaran kuesioner pada 81 orang responden. Untuk lebih jelasnya karakteristik responden tersebut akan dijelaskan sebagai berikut :

1. Berdasarkan karakteristik usia menunjukkan bahwa 5 orang responden $(6,2 \%)$ berumur pada rentang 26-30 tahun. 18 orang responden $(22,2 \%)$ berumur pada rentang 31-35 tahun. Selanjutnya 38 orang responden $(46,9 \%)$ berumur pada rentang 36-40 tahun. Sedangkan sisanya, sebanyak 20 orang $(24,7 \%)$ berumur di atas 40 tahun.

2. Berdasarkan jenis kelamin, diketahui bahwa sebagian besar responden atau sebanyak 49 orang $(60,5 \%)$ berjenis kelamin laki-laki, dan sisanya sebanyak 32 orang lagi $(39,5 \%)$ berjenis kelamin perempuan. Kemudian berdasarkan pendidikan terakhir, dapat dilihat bahwa responden tamatan SMA/sederajat hanya 4 orang (4,9\%), kemudian yang lulusan Diploma berjumlah 24 orang $(29,6 \%)$, selanjutnya 50 orang responden $(61,7 \%)$ atau lebih dari setengah responden merupakan tamatan sarjan S-1, dan hanya 3 orang $(3,7 \%)$ saja responden yang lulusan pascasarjana. 
3. Berdasarkan pengalaman kerja responden, diketahui hampir dari setengah responden atau sebanyak 40 orang $(49,4 \%)$, telah bekerja diantara rentang 6-10 tahun, selanjutnya sebanyak 23 orang responden $(28,4 \%)$ telah bekerja lebih dari 10 tahun, dan sisanya sebanyak 18 orang $(22,2 \%)$ dengan masa kerja kurang dari 5 tahun.

\section{Analisis Regresi Linier Berganda}

\section{Pengaruh Variabel Independent Terhadap Variabel Dependent}

Seperti dikemukakan pada rumusan masalah dan hipotesis penelitian yaitu menganalisis variabel Implementasi SAP Berbasis Akrual $\left(\mathrm{X}_{1}\right)$, Efektivitas Fungsi Pengawasan $\left(\mathrm{X}_{2}\right)$, sebagai variabel bebas (independent variabel) baik secara simultan maupun parsial, maka untuk menjelaskan didasarkan kepada analisis regresi linier berganda seperti yang terlihat pada tabel berikut ini :

Tabel 4.1

Pengaruh Masing-masing Variabel Bebas Terhadap Variabel terkait

\begin{tabular}{|c|c|c|c|c|c|c|}
\hline \multirow[b]{2}{*}{ Model } & \multirow[t]{2}{*}{ Nama Variabel } & \multirow[t]{2}{*}{$\beta$} & \multicolumn{2}{|c|}{$\begin{array}{l}\text { Unstandardized } \\
\text { Coefficients }\end{array}$} & \multirow[t]{2}{*}{ thitung } & \multirow[t]{2}{*}{ Sig } \\
\hline & & & Std,errorr & Beta & & \\
\hline \multirow[t]{8}{*}{1} & (Constant) & 2,072 & 0,379 & & 5,463 & 0,000 \\
\hline & $\begin{array}{l}\text { Implementasi SAP Berbasis Akrual } \\
\left(X_{1}\right)\end{array}$ & 0,197 & 0,067 & 0,299 & 2,953 & 0,004 \\
\hline & Efektivitas Fungs Pengawasan $\left(X_{2}\right)$ & 0,254 & 0,082 & 0,313 & 3,090 & 0,003 \\
\hline & Koefisiensikorelasi & 0,654 & \multirow{5}{*}{\multicolumn{4}{|c|}{$\begin{array}{l}\text { a. Jumlah data } 81 \text { responden } \\
\text { b. Prediktor variabel karakteristik } \\
\text { kualitatifimplementasi SAP berbassis } \\
\text { akrual(X1) } \\
\text { c. Prediktor variabel karakteristik } \\
\text { kualitatif efektivitas fungsi } \\
\text { pengawasan (X2) } \\
\text { d. variabel dependen : kineria keuangan } \\
\text { Penkab Aceh Besar }\end{array}$}} \\
\hline & R square & 0,406 & & & & \\
\hline & Fhitung & 10,103 & & & & \\
\hline & F tabel & 3,110 & & & & \\
\hline & Sig $\mathrm{F}$ & 0,000 & & & & \\
\hline
\end{tabular}

Berdasarkan hasil output komputer melalui program SPSS, maka diperoleh persamaan regresi berganda sebagai berikut : $\mathrm{Y}=2,072+0,197\left(\mathrm{X}_{1}\right)+0,254\left(\mathrm{X}_{2}\right)+\mathrm{e}$

Dari persamaan regresi di atas dapat dijelaskan hasil penelitian sebagai berikut :

2. Koefisien Regresi ( $\beta$ )

a. Koefisien konstanta sebesar 2,072. Artinya bilamana variabel, Implementasi SAP Berbasis Akrual $\left(\mathrm{X}_{1}\right)$ dan Efektivitas Fungsi Pengawasan $\left(\mathrm{X}_{2}\right)$ dianggap konstan, maka besarnya kinerja sebesar 2,072

b. Besarnya koefisien variabel Implementasi SAP Berbasis Akrual sebesar 0,197 artinya setiap kenaikan $100 \%$ perubahan dalam variabel Implementasi SAP Berbasis Akrual secara relatif akan meningkatkan Kinerja Keuangan Pemkab Aceh Besar sebesar 19,7\% dengan asumsi variabel Efektivitas Fungsi Pengawasan dianggap konstan.

c. Besarnya koefisien variabel Efektivitas Fungsi Pengawasan sebesar 0,254 artinya setiap kenaikan $100 \%$ perubahan dalam variabel Efektivitas Fungsi Pengawasan secara relatif akan meningkatkan Kinerja Keuangan Pemkab Aceh Besar sebesar $25,4 \%$ dengan asumsi variabel Implementasi SAP Berbasis Akrual dianggap konstan.

Berdasarkan hasil analisis di atas dapat diketahui bahwa dari 2 (dua) variabel yang diteliti, diketahui bahwa kedua variabel independent memiliki pengaruh terhadap Kinerja Keuangan Pemerintah Kabupaten Aceh Besar, sedangkan pengaruh yang paling dominan terhadap Kinerja Keuangan Pemerintah Kabupaten Aceh Besar dari kedua variabel independen tersebut adalah variabel Efektivitas Fungsi Pengawasan $\left(\mathrm{X}_{2}\right)$

\section{Koefisien korelasi ( $R$ ) dan determinasi}

\section{$\left(\mathbf{R}^{2}\right)$}

Untuk melihat hubungan dan pengaruh variabel bebas terhadap kinerja Pemerintah Kabupaten Aceh Besar berdasarkan korelasi dan determinasi seperti dijelaskan pada tabel berikut ini:

Tabel 4.2

Tabel Model Summary

\begin{tabular}{|l|l|l|l|l|}
\hline $\mathbf{R}$ & $\mathbf{R 2}$ & $\begin{array}{l}\text { Adjusted } \\
\mathbf{R 2}\end{array}$ & $\begin{array}{l}\text { Std. } \\
\text { Error of } \\
\text { the } \\
\text { estimate }\end{array}$ & Keterangan \\
\hline 0,654 & 0,406 & 0,285 & 0,2546 & Korelasi sedang \\
\hline
\end{tabular}

Sumber : Data Primer, 2017 (diolah) 
1. Koefisien korelasi $(\mathrm{R})=0,654$ yang menunjukkan bahwa derajat hubungan antara variabel bebas dengan variabel terikat sebesar $65,4 \%$. Artinya kinerja keuangan Pemerintah Kabupaten Aceh Besar erat hubungannya dengan Implementasi SAP Berbasis Akrual $\left(\mathrm{X}_{1}\right)$ dan Efektivitas Fungsi Pengawasan $\left(\mathrm{X}_{2}\right)$.

2. Koefisien determinasi $\left(\mathrm{R}^{2}\right)$ sebesar 0,406. Artinya sebesar 40,6\% Implementasi SAP Berbasis Akrual $\left(\mathrm{X}_{1}\right)$ dan Efektivitas Fungsi Pengawasan $\left(\mathrm{X}_{2}\right)$ secara bersama-sama berpengaruh terhadap kinerja keuangan Pemerintah Kabupaten Aceh Besar, sedangkan selebihnya yaitu sebesar 59,4\% dipengaruhi oleh faktor-faktor lain di luar daripada yang menjadi variabel penelitian ini, seperti faktor motivasi kerja, faktor pemberian insentif, faktor komitmen organisasi, faktor pendidikan dan pelatihan, serta faktor-faktor lain yang berhubungan dengan kinerja.

\section{Pengujian Secara Parsial (Uji-t)}

Uji parsial digunakan untuk menguji secara parsial masing-masing variabel independen terhadap variabel dependen, pengambilan keputusan dilakukan dengan membandingkan nilai $t_{\text {hitung }}$ dengan $t_{\text {tabel}}$, pada taraf signifikansi $\alpha=5 \%$. Hasil perhitungan yang diperlihatkan pada tabel 4.6 berikut ini:

Tabel 4.3

Uji Parsial (t-test)

\begin{tabular}{|l|l|l|l|}
\hline No & Variable Independen & $\mathrm{t}$ & Sig. \\
\hline 1. & $\begin{array}{l}\text { Implementasi SAP Berbasis } \\
\text { Akrual (X1) }\end{array}$ & 2,953 & 0,004 \\
\hline 2. & $\begin{array}{l}\text { Efektivitas Fungsi Pengawasan } \\
(\mathrm{X} 2)\end{array}$ & 3,090 & 0,003 \\
\hline
\end{tabular}

Sumber : Data Primer, 2017 (diolah)

Tabel di atas menunjukkan variabel faktor-faktor yang mempengaruhi kinerja keuangan Pemerintah Kabupaten Aceh Besar, secara parsial, antara lain :

a. Variabel Implementasi SAP Berbasis Akrual
Hasil penelitian terhadap variabel Implementasi SAP Berbasis Akrual $\left(\mathrm{X}_{1}\right)$ diperoleh $t_{\text {hitung }}(2,953)$ dan $t_{\text {tabel }}(1,990)$. Hasil perhitungan ini menunjukkan bahwa $t_{\text {hitung }}>t_{\text {tabel }}$ dengan signifikansi sebesar 0,004 atau probabilitas di bawah $\alpha=5 \%$. Sehingga dapat ditarik kesimpulan bahwa menerima $\mathrm{Ha}_{1}$, dan menolak $\mathrm{Ho}_{1}$. Dengan demikian hasil perhitungan statistik menunjukkan bahwa secara parsial variabel Implementasi SAP Berbasis Akrual $\left(\mathrm{X}_{1}\right)$ berpengaruh secara signifikan terhadap kinerja keuangan Pemerintah Kabupaten Aceh Besar.

\section{b. Variabel Efektivitas Fungsi}

\section{Pengawasan}

Hasil penelitian terhadap variabel Efektivitas Fungsi Pengawasan $\left(\mathrm{X}_{2}\right)$ diperoleh $t_{\text {hitung }}(3,090)$ dan $t_{\text {tahel }}(1,990)$. Hasil perhitungan ini menunjukkan bahwa $t_{\text {hitung }}>t_{\text {tabel }}$ dengan signifikansi sebesar 0,003 atau probabilitas di bawah $\alpha=5 \%$. Sehingga dapat ditarik kesimpulan bahwa menerima $\mathrm{Ha}_{2}$, dan menolak $\mathrm{Ho}_{2}$ Dengan demikian hasil perhitungan statistik menunjukkan bahwa secara parsial variabel Efektivitas Fungsi Pengawasan berpengaruh secara signifikan terhadap kinerja keuangan Pemerintah Kabupaten Aceh Besar.

\section{Pengujian Secara Simultan (Uji-F)}

Uji simultan dilakukan untuk mengetahui apakah semua variabel independen yaitu pengawasan intern mempunyai pengaruh terhadap kinerja Pemerintah Kabupaten Aceh Besar, seperti terlihat pada tabel berikut ini :

Tabel 4.4

Analisis of Variance (Anova)

\begin{tabular}{|l|l|l|l|l|l|l|}
\hline Model & $\begin{array}{l}\text { Sum } \\
\text { of } \\
\text { Squar } \\
\text { es }\end{array}$ & $\begin{array}{l}\text { D } \\
\text { f }\end{array}$ & $\begin{array}{l}\text { Mean } \\
\text { Squar } \\
\text { es }\end{array}$ & $\begin{array}{l}\text { F }_{\text {hitun }} \\
\text { g }\end{array}$ & $\begin{array}{l}\text { F tabe }_{1} \\
\mathbf{l}\end{array}$ & Sig \\
\hline $\begin{array}{l}\text { Regres } \\
\mathrm{i}\end{array}$ & 1,937 & 2 & 0,968 & $\begin{array}{l}10,10 \\
3\end{array}$ & $\begin{array}{l}3,11 \\
0\end{array}$ & $\begin{array}{l}0,00 \\
0\end{array}$ \\
\hline
\end{tabular}




\begin{tabular}{|l|l|l|l|l|l|l|}
\hline $\begin{array}{l}\text { Residu } \\
\text { al }\end{array}$ & 7,477 & 7 & 0,096 & & & \\
\hline Total & 9,414 & 8 & & & & \\
& 0 & & & & \\
\hline
\end{tabular}

Sumber : Data Primer, 2017 (diolah)

Pengujian dilakukan dengan Anova yang membandingkan nilai $\mathrm{F}_{\text {hitung }}$ dengan $\mathrm{F}_{\text {tabel }}$ pada tabel 4.7 menunjukkan $F_{\text {hitung }}$ sebesar 10,103, sedangkan $\mathrm{F}_{\text {tabel }}$ pada tingkat signifikansi $\alpha=$ 5\% adalah sebesar 3,110. Dari perhitungan tersebut memperlihatkan bahwa $\mathrm{F}_{\text {hitung }}>\mathrm{F}_{\text {tabel }}$ $(10,103>3,110)$, sehingga dapat ditarik kesimpulan bahwa merima $\mathrm{Ha}_{3}$ (Hipotesis alternative) dan menolak $\mathrm{Ho}_{3}$ (Hipotesis nol), artinya bahwa variabel Implementasi SAP Berbasis Akrual $\left(\mathrm{X}_{1}\right)$ dan Efektivitas Fungsi Pengawasan $\left(\mathrm{X}_{2}\right)$ secara bersama-sama berpengaruh secara signifikan terhadap kinerja keuangan Pemerintah Kabupaten Aceh Besar.

Dengan demikian terbukti bahwa terdapat pengaruh yang signifikan antara, Implementasi SAP Berbasis Akrual $\left(\mathrm{X}_{1}\right)$ dan Efektivitas Fungsi Pengawasan $\left(\mathrm{X}_{2}\right)$ terhadap kinerja keuangan Pemerintah Kabupaten Aceh Besar, dengan demikian hipotesis alternatif $\left(\mathrm{Ha}_{3}\right)$ yang diajukan diterima dan menolak hipotesis nol ( $\left.\mathrm{Ho}_{3}\right)$, karena diperoleh nilai $\mathrm{F}_{\text {hitung }}>\mathrm{F}_{\text {tabel, }}$, dengan tingkat probabilitas Sig $(0,000)$.

\section{Pembuktian Hipotesis}

Analisis yang digunakan untuk pengujian hipotesis adalah dengan menggunakan analisis regresi linier berganda. Berdasarkan hasil analisis regresi linier berganda dengan menggunakan perhitungan program komputerisasi SPSS versi 22.0 diperoleh persamaan regresi:

$$
Y=2,072+0,197\left(X_{1}\right)+0,254\left(X_{2}\right)+e
$$

Untuk menguji signifikansi dari persamaan regresi linier tersebut digunakan analisis varian untuk regresi. Berdasarkan hasil perhitungan diperoleh $\mathrm{F}_{\text {hitung }}>\mathrm{F}_{\text {tabel }}$ yaitu $10,103>3,110$, maka dapat disimpulkan bahwa persamaan regresi tersebut signifikan.
Hubungan antara variabel independent $\left(\begin{array}{lll}X_{1} & \text { dan } & X_{2}\end{array}\right)$ dengan kinerja keuangan Pemerintah Kabupaten Aceh Besar (Y) dapat diketahui dari nilai koefesien korelasi. Berdasarkan hasil analisis dengan program komputasi SPSS versi 22.0 diperoleh koefesien korelasi atau $\mathrm{R}$ sebesar 0,654. Selanjutnya koefesien korelasi tersebut dapat diuji dengan menggunakan uji-t. Berdasarkan hasil uji-t kedua variabel sangat berpengaruh terhadap kinerja keuangan Pemerintah Kabupaten Aceh Besar, dimana nilai $t_{\text {hitung }}$ dari masing-masing variabel tersebut lebih besar dari tabel $(1,990)$.

Besarnya pengaruh atau kontribusi yang diberikan oleh pengaruh variabel Implementasi SAP Berbasis Akrual dan Efektivitas Fungsi Pengawasan terhadap kinerja keuangan Pemerintah Kabupaten Aceh Besar dapat diketahui dari nilai koefisien determinasi atau $\mathrm{R}^{2}$. Berdasarkan hasil perhitungan diperoleh nilai $\mathrm{R}^{2}=0,406$ yang berarti besarnya pengaruh Implementasi SAP Berbasis Akrual dan Efektivitas Fungsi Pengawasan terhadap kinerja keuangan Pemerintah Kabupaten Aceh Besar adalah sebesar 40,6\%. Dari hasil tersebut menunjukkan bahwa selain variabel Implementasi SAP Berbasis Akrual dan Efektivitas Fungsi Pengawasan, kinerja keuangan Pemerintah Kabupaten Aceh Besar juga dipengaruhi variabel lain yang tidak dikaji dalam penelitian ini sebesar 59,4\%. Variabel-variabel tersebut seperti faktor motivasi kerja, faktor pemberian insentif, faktor komitmen organisasi, faktor pendidikan dan pelatihan, serta faktor-faktor lain yang berhubungan dengan kinerja karyawan.

Dalam penelitian ini jelas, bahwa Implementasi SAP Berbasis Akrual berpengaruh signifikan terhadap kinerja keuangan pemerintah daerah, khususnya Kabupaten Aceh Besar. Hal ini menunjukan bahwa Implementasi SAP Berbasis Akrual 
dapat memberikan dukungan terhadap kinerja keuangan pemerintahan daerah sehingga lebih terukur, terstruktur dan dapat dibandingkan.

Selanjutnya, dalam penelitian ini diketahui juga bahwa Efektivitas Fungsi Pengawasan juga memberikan pengaruh yang signifikan terhadap kinerja keuangan Pemerintah Kabupaten Aceh Besar. Efektivitas Fungsi Pengawasan yang berjalan dengan baik akan menciptakan laporan keuangan yang baik pula, sekaligus akan memberikan dukungan berupa responsivitas, responsibilitas, dan akuntabilitas sebuah instansi daerah, dalam hal ini adalah Pemerintah Kabupaten Aceh Besar. Semakin baik pengawasan intern yang dilaksanakan akan memberikan dampak semakin baik kinerja Pemerintah daerah yang dicapai.

\section{KESIMPULAN/CONCLUSSION}

\section{Kesimpulan}

Berdasarkan hasil penelitian dan pembahasan tentang Implementasi SAP Berbasis Akrual dan Efektivitas Fungsi Pengawasan terhadap kinerja keuangan Pemerintah Kabupaten Aceh Besar, maka dapat disimpulkan beberapa hal sebagai berikut :

1. Terdapat hubungan linier positif dan cukup erat antara variabel Implementasi SAP Berbasis Akrual terhadap kinerja keuangan Pemerintah Kabupaten Aceh Besar.

2. Terdapat hubungan linier positif dan cukup erat antara variabel Efektivitas Fungsi Pengawasan terhadap kinerja keuangan Pemerintah Kabupaten Aceh Besar.

3. Hasil Uji $t$ menandakan besarnya pengaruh variabel Implementasi SAP Berbasis Akrual secara parsial terhadap kinerja keuangan Pemerintah Kabupaten
Aceh Besar, karena memiliki nilai $t_{\text {hitung }}$ yang lebih besar dari nilai $t_{\text {tabel. }}$.

4. Hasil Uji t menandakan besarnya pengaruh variabel Efektivitas Fungsi Pengawasan secara parsial terhadap kinerja keuangan Pemerintah Kabupaten Aceh Besar, karena memiliki nilai $t_{\text {hitung }}$ yang lebih besar dari nilai $t_{\text {tabel. }}$.

5. Hasil uji F membuktikan bahwa, Implementasi SAP Berbasis Akrual dan Efektivitas Fungsi Pengawasan secara simultan berpengaruh terhadap kinerja keuangan Pemerintah Kabupaten Aceh Besar.

\section{Saran}

Berdasarkan kesimpulan di atas, maka peneliti memberikan beberapa saran sebagai berikut:

1. Kepada Pemerintah Daerah Kabupaten Aceh Besar,Bahwa dalam rangka implementasi SAP berbasis akrual di Pemerintah Kabupaten Aceh Besar yaitu:

a) Perlu adanya percepatan pelaksanaan kegiatan-kegiatan yang telah di anggarkan sebelumnya,seperti peningkatan konektifitas jaringan SIMDA, peningkatan kemampuan pemahaman akuntansi akrual,tidak hanya definisin akrual saja tetapi lebih kepada kemampuan menganalisa dan memahami permasalahan-permasalahan terkait akuntansi akrual.

b) Selain itu diklat yang di adakan harus lebih mengedepankan praktik di lapangan untuk memenuhi kebutuhan SDM karena masih terbatas nya formasi SDM yang mempunyai kompetensi di bidang akuntansi perguruan tinggi,dan di perbanyak diklat-diklat terkait pengelolaan keuangan.

c) Sedangkan dalam aspek IT,di perlukan percepatan pengembangan 
aplikasi keuangan agar dapat menghasilkan laporan keuangan secara akrual dengan mengintegrasikan aplikasi-aplikasi lain seperti aplikasi pengelolaan pendapatan dan aplikasi pengelolaan aset.

2. Bagi peneliti lain yang akan melanjutkan penelitian ini,di harapkan untuk dapat meneruskan dan mengembangkan penelitian ini pada masa yang akan datang dengan lebih komprehenshif,melalui penelitian ini yang lebih mendalam tentang faktorfaktor lain yang mempengaruhi kinerja. Di karenakan variabel-variabel bebas dalam penelitian ini belum mampu menjelaskan pengaruhnya terhadap variabel terikat di atas $90 \%$, penelitian ini hanya mampu menjelaskan pengaruh nya terhadap terikat sebesar $40,6 \%$. Dalam penelitian ini selanjutnya perlu menambahkan variabel bebas,seperti insentif dan pelatihan. Agar menghasilkan penelitian baru yang dapat membantu perusahaan,lembaga atau instansi dalam meningkatkan kinerja keuangannya.

\section{DAFTAR PUSTAKA}

Abdullah, M. Faisal (2013) Dasar-dasar Manajemen

Keuangan, Universitas Muhammadiyah, Malang.

Adisasmita Rahardjo (2011) Manajemen Keuangan Daerah, Yogyakarta: Graha Ilmu.

Arif Soyan Mirrian et.al (2016) Manajemen Pemerintah, Jakarta: Universitas Terbuka.

Arikunto (2010) Prosedur Penelitian. Jakarta: Reneka Cipta.

Auditya Lucy dan Husaini Lismawati (2013) Analisis Pengaruh Akuntabilitas Dan Transparansi Pengelolaan Keuangan Daerah Terhadap Kinerja Pemerintah Daerah Journal Fairness Volume 3, Nomor 1, Program Magister Akuntansi Universitas Bengkulu.

Badruzaman, Jajang dan Chairunnisa, Irna (2011) Pengaruh Implementasi Sistem Akuntabilitas Kinerja Instansi Pemerintah (SAKIP) terhadap Penerapan Good Governance. Jurnal Akuntansi dan Bisnis AUDI.

Bastian, Indra (2010) Akuntansi Sektor Publik: Suatu Pengantar. Jakarta: Erlangga.
Dharma, Setia E (2014) Pengaruh Kejelasan Sasaran Anggaran dan Sistem Pengendalian Akuntansi terhadap Kinerja Manajerial dengan Komitmen Organisasi sebagai Variable Pemoderasi pada Pemerintah Daerah Kabupaten/ Kota Provinsi DI Yogyakarta). Denpasar Bali. Simposium Nasional Akuntansi VII, Desember

Fahmi Ilham (2011) Manajemen Kinerja, Alfabeta, Bandung.

Fahroji Ikhwan dan Mokh Najih (2011) Menggugat Peran DPR dan BPK Dalam Reformasi Keuangan Negara, Trans Publishing, Malang.

Halim, Abdul (2013) Akuntansi Sektor Publik: Akuntansi Keuangan Daerah. Jakarta: Salemba Empat.

Hoesada, Jan (2010) Accrual Budgeting and Accrual Accounting pada Pemerintahan NKRI. Jurnal Akuntansi/Tahun XIV, No. 01, Januari 2010: 113124.

Ikatan Akuntansi Indonesia (2016) Workshop Penyusunan Laporan Keuangan Pemerintah, Jakarta

Kementerian Dalam Negeri (2014) Konsep Siklus Akuntansi di Pemerintahan Daerah, Diroktorat Jenderal Keuangan Daerah Jakarta.

Kementerian Keuangan (2014) Gambaran Umum Akuntansi Berbasis Akrual, Modul Pelatihan Kementerian Keuangan, Jakarta.

Kementerian Keuangan Republik Indonesia (2014) Gambaran Umum Akuntansi Berbasis Akrual, Modul Program Percepatan Akuntabilitas Pemerintah Pusat, Jakarta.

Lamonisil Sony (2016) Analisis Penerapan Standar Akuntansi Berbasis Akrual Pada Pemerintah Kota Tomohon Jurnal EMBA Vol 1 No 4 Fakultas Ekonomi dan Bisnis, Jurusan Akuntansi Universitas Sam Ratulangi Manado.

Mahmudi (2013) Manajemen Kinerja Sektor Publik. Yogyakarta: UPP STIM YKPN.

Mardiasmo (2013) Akuntansi Sektor Publik, ANDI, Yogyakarta.

Muhammad Arifai Dan Edi Abral (2013) Faktor Yang Mempengaruhi Implementasi Kinerja Keuangan Pemerintah Daerah Jurnal Ekonomi Dan Bisnis Vol 14, No. 1 Tata Niaga Politeknik Negeri Lhokseumawe.

Mulyadi (2011) Sistem Perencanaan dan Pengendalian manajemen, Edisi ketiga, Salemba Empat, Jakarta.

Nawawi Zaidan (2013) Manajemen Pemerintahan, Rajagrafindo, Jakarta.

Nordiawan Deddi (2012) Akuntansi Sektor Publik Jakarta: Salemba Empat.

Nunuy Afiah Nur (2010) Akuntansi Pemerintahan: Implementasi Keuangan Pemerintah Daerah Jakarta: Kencana.

Pongoh Marsel (2012) Analisis Laporan Keuangan Untuk Menilai Kinerja Keuangan PT. Bumi Resources Tbk. Jurnal EMBA Vol.1 No.3 Fakultas Ekonomi dan Bisnis, Jurusan Akuntansi Universitas Sam Ratulangi Manado.

Putri Wulan Suci Ika dan Ikhsan Budi Riharjo (2016) PELAPORAN KINERJA INSTANSI 
PEMERINTAH (Studi Pada Kantor Kecamatan Rungkut Kota Surabaya) Jurnal Ilmu dan Riset Akuntansi : Vol 5, No 5, Sekolah Tinggi Ilmu Ekonomi Indonesia (STIESIA) Surabaya.

Rasdianto Erlina (2013) Akuntansi Keuangan Daerah Berbasis Akrual. Medan: Brama Ardian.

Republik Indonesia, Peraturan Presiden Republik Indonesia Nomor 29 tahun 2014 tentang Sistem Akuntabilitas Kinerja Instansi Pemerintah.

Republik Indonesia, Undang- Undang No. 71/2010 Tentang Standar Akuntansi Pemerintahan.

Sitorus Selvina et.al (2015) Analisis Kesiapan Penerapan Standar Akuntansi Pemerintah Berbasis Akrual Berdasarkan PP. NO. 71 Tahun 2010 Pada Dinas Pendapatan Pengelolaan Keuangan Dan Barang Milik Daerah Kota Tomohon Jurnal EMBA Vol.3 No.1 Universitas Sam Ratulangi Manado.

Soeradi H (2014) Pengeloaan Keuangan Negara di Era Otonomi, Yogyakarta: Graha Ilmu.

Sugiyono (2011). Metode Penelitian Kuantitatif dan Kualitatif. CV.Alfabeta: Bandung.

Sukmana Wawan dan Lia Anggarsari (2009) Pengaruh Pengawasan Intern dan Pengawasan eksternal Terhadap Kinerja Pemerintah Daerah (Survei pada Satuan Kerja Perangkat Daerah Kota Tasikmalaya) Jurnal Akuntansi FE Unsil, Vol. 4, No. 1, 2009.

Sumarsono (2010) Manajemen Keuangan Pemerintahan, Yogyakarta: Graha Ilmu.

Tarigan Erwinton Putra Antonius dan Lastria Nurtanzila (2013) Standar Akuntansi Pemerintahan dalam
Mewujudkan Akuntabilitas dan Transparansi Pengelolaan Keuangan Daerah Jurnal Kebijakan \& Administrasi Publik JKAP Vol 17 No 1 Pascasarjana MKP FISIPOL UGM.

Tika Pabundu (2012) Budaya Organisasi dan Peningkatan Kinerja Perusahaan, Bumi Akara, Jakarta.

Tisnawati, Ernie Sule dan Saefullah Kurniawan (2014) Pengantar Manajemen. Granada Media, Jakarta.

Wibawa Dimas Satria et.al (2013) Pengaruh Implementasi Standar Akuntansi Pemerintahan Berbasis Akrual Dan Efektivitas Fungsi Pengawasan Terhadap Kinerja Keuangan Pada Pemerintah Daerah Kota Tegal Jurnal Trikonomika Vol 12, No. 2 Universitas Jenderal Soedirman.

Wibowo (2014) Manajemen Kinerja, Rajawali Persada, Jakarta.

Wina Intan Permata Haska dan Khairani Siti (2015) Pengaruh Penerapan Standar Pelaporan Akuntansi Sektor Publik Dan Pengawasan Terhadap Akuntabilitas Kinerja Instansi Pemerintshj (Studi Kasus Dispenda Kota dan Dishub Prov). Jurnal Ilmiah Akuntansi, STIE MDP 